\title{
FACTORS, INFLUENCING THE EMERGENCE OF CHILD SPEECH DISORDER
}

\author{
Irēna Miltiņa \\ Dace Augstkalne \\ Riga Teacher Training and Educational Management, Latvia
}

\begin{abstract}
Speech disorders can have various causes, expression of the pathological processes and severity. Studies in Latvia show that already in early childhood both language development deficiency and language development delay are evident.

These phenomena continue also in the pre-school age where in $30-60 \%$ of cases show nonconformity of speech and language development to the set norms for the particular age.

The established facts illustrate the importance of learning about the causes of speech disorder, because the disorders in sound pronunciation and phonematic perception, as well as insufficient vocabulary affect both the acquisition of pupil's reading and writing skills and the understanding of verbal instructions.
\end{abstract}

Keywords: endogenous, exogenous factor, speech disorders.

\section{Introduction}

Speech disorders - deviations in speech development with various etiology (causes of illness or pathological condition), pathogenesis (mechanism of the illness development, pathological process of conditions), severity (Lūse, Miltina, Tūbele, 2012).

Factor - a condition that causally affects the process - causes, defines, facilitates or strengthens it (Svešvārdu vārdnīca, 1999).

Speech disorders can have physiological (connected with immaturity of the cerebral structure and the peripheral part of speech apparatus) and pathological (changes due to ilness) nature. Pathological speech disorders, depending on the location, are divided in central and peripheral, but by the character of the disorder - in organic and functional (Волкова, 2004; Парамонова, 1997; Трошин, Жулина, 2005).

Already in 2003 A.Irbe, S.Lindenberga and L.Mikselsone (2003) in the framework of the "Center for Healthy Development of Children" program inspected 37 children aged 2 to 3 . The inspection established that only 8 children had mastered speech and language corresponding to the conventional age norms; 7 children showed insufficient development of language system, but 22 children - language development delay.

A.Falka (2012) notes that in Latvia $30-60 \%$ of children in preschool education institutions show insufficient speech and language development level. 
G.Tomele, in turn, indicates that pupils, starting $1^{\text {st }}$ grade, display disorders of sound pronunciation and phonematic perception, insufficient vocabulary and understanding of verbal instructions (Tomele, 2013).

The above mentioned facts illustrate the topicality of this issue. The speech and language disorders in age stages - early childhood $\rightarrow$ preschool $\rightarrow$ early school age - confirm the idea that a determined, planned and effective work on mastering the speech and language skills necessary for children can only be realized if the factors influencing the emerging of child's speech disorders are defined, if the adults are informed about the possible speech/ language disorders and if there is cooperation between a teacher-speech therapist $\leftrightarrow$ specialists $\leftrightarrow$ adults.

The aim of this article is to argument the possible causes for the emergence of child speech disorders.

\section{Factors influencing the development of the child}

The development of child's speech, as well as the development of the child as a whole is influenced by both endogenous (induced by internal causes) and exogenous (induced by external causes) factors (See Figure 1).

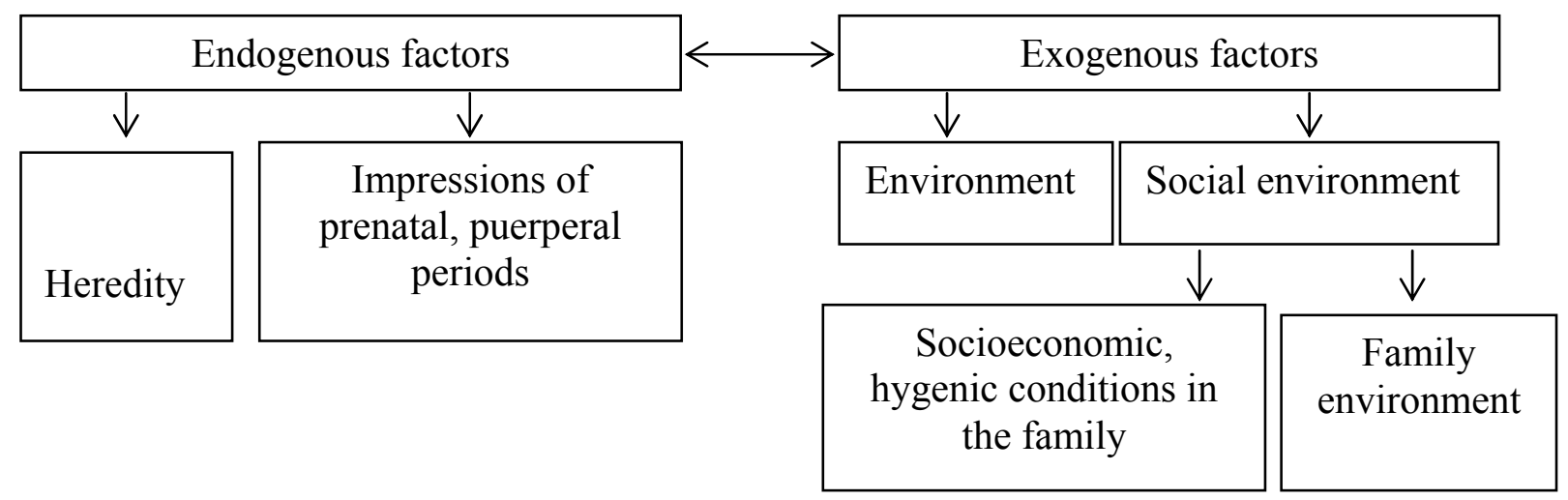

Figure 1. Factors influencing the development of the child

(Geske, 2005; Puškarevs, 2001)

\section{Endogenous factors}

An important factor that affects the physical and psychic development is heredity. It is the ability of an organism to transfer its characteristics to coming generations. This factor largely determines not only the aggregate anatomic and physiological regularity of the organism, its functioning and reaction to environmental conditions, but also the character, intellectual abilities and the simplest functions of the psyche - senses.

The impact of heredity is observed when there is organic damage in the level of genes or chromosomes. Even though genetically hereditary disorders are not always dangerous for life (for example, as a consequence - shortsightedness or farsightedness), deviations in eyesight can make it harder for the child to 
learn reading and writing skills. A widespread pathology of chromosomes is the Down's syndrome that is usually accompanied with disorders of mental development, speech/ language, aberrances in many organ systems.

When the child is born, not only the deviations connected with heredity appear, but also the changes obtained through the presence of unfavorable factors during prenatal period, i.e., from the splitting of the ovule until the full formation of the fetus.

Teratogenic (causing deformity) factors can be:

- $\quad$ physical (noise, mechanical damage, ionized irradiance etc.);

- $\quad$ chemical (medicaments, air pollution etc.);

- biological (viruses, bacteria, fungi).

E.Baladina (Баладина, 2010, 6), studied risk factors in children with cleft lip and palate (rhinolalia), noted the following teratogenesof disorder origin:

- $\quad$ harmful habits of parents $(2,45 \%)$;

- gynecological and sexually transmitted diseases (STD) (3,4\%; $0,98 \%$;

- $\quad$ damages connected with occupation $(3,1 \%)$;

- adverse mutual relationship in the family $(2,97 \%)$.

Most often the influence comes from the set of harmful factors, because rhinolalia (the previously described case) is accounted as a multi-factorial hereditary disorder that is manifested in facial deformities, deviations of suction, breathing and speech/ language functions.

A report performed and published in 2009, "The Health of Mother and Child in the Prenatal Period" illustrates the substantial influence of mother's prenatal health and lifestyle habits on the child. The data of the newborn registry show that during pregnancy approximately $10 \%$ of the new mothers have smoked, $0.5 \%$ - used alcohol, and $0.1 \%$ - used drugs. The morbidity of the mother with various contagious diseases (STD, rubella, acute respiratory infection (ARI) etc.) has been the main etymological factor in $40 \%$ of premature deliveries.

Child's development is, undoubtedly, influenced by the conditions of the arrival of the child, i.e. how successful/ unsuccessful is the process of labor. Risk for difficult labor increases with the age of the mother (increased frequency of problems), as well as in cases of multi-fetal pregnancy and different infections. One of the main problems is premature delivery where the etiology is multi-factorial (Skrule, Štāle, Upmale, viewed on 12.12.2014).

From the moment of conception, through gestation period, and until the delivery, the new family has a particular responsibility for the physical and neuro-psychical health of the baby, therefore medical, psychological and pedagogic education of the new parents is very important. 


\section{Exogenous factors}

One of the factors externally influencing human organism is the environmental ecosystem where child's development takes place. Climate as a part of the mentioned system influences the tendencies of growth, cosmic component (sun radiation, light, heat) depending on the dose influences organism both in a positive and negative manner, while the biological component (viruses, bacteria, pathogenic fungi) advance/ obstructs child's health and development in general (Puškarevs, 2001; Geske, 2005).

The most intensive facilitator/ disturber of child's development is the first micro-social environment - family.

The socio-economic situation in the country, society and family in general determines whether the provision of child's perceptive, domestic and hygienic arrangements corresponds/ does not correspond to the needs of the baby.

An essential factor that defines the dominant atmosphere between the adults in the family is the opinion of parents regarding the child as a value. This factor is closely related with love as an emotional phenomenon when the child is loved just as he is, regardless of whether the child lives up to the expectations of parents (Kempbels, 1998).

Child has his first emotional bonds with his mother. Child cannot yet express himself, but very early on he can recognize his mother's voice, intonation, obtaining information from her touches, facial expressions, and glances. Kind, emotionally generous interaction, child's sensitive experience, mother's comments, expressive environment of objects undeniably facilitates child's "languaging" - development of speech (Miltina, 2013). Mother is the first person that satisfies the physiological, love and security needs which creates the attachment phenomenon. Attachment as emotional bond where the relationship is based on evolution and survival, in the end creates a sense of security in the child - mutual trust, understanding and support between the child and the adult.

The author of the "Attachment theory" J. Bowlby notes that three models of attachment can develop between a child and an adult:

- $\quad$ secure attachment (child is certain that his parents will be available in situations unfavorable to him),

- $\quad$ anxious-resistant insecure attachment(child is not sure if his parents will be available, supportive and helpful when he needs them),

- anxious-avoidant insecure attachment (child is not sure that when he needs someone who could take care of him, there will be sympathy and help).

In continuation to the attachment models J. Bowlby notes on the direction of child development - children with sensitive and sympathetic parents will most likely develop successfully. However, those children whose parents are 
insensitive, unsympathetic, inattentive or deprecatory are more likely to deviate towards direction conflicting with healthy development (Boulbijs, 1998).

Consequently, if the mutual parent $\leftrightarrow$ child relationship are tended towards encouragement and support then the child obtains confidence of what he can and is able to do, he is not afraid of failures because he knows that everyone can make a mistake. The basic trust in world is secured in the child - he loves himself and people surrounding him, he is brave, active unafraid to express his thoughts verbally, choose his activities and finish the task in hand.

The significance of the interaction style between the mother and child in the facilitation/ obstruction of speech/ language development is greatly illustrated in the research made by A.Ivanova (Иванова, 2004) where she describes four mother $\leftrightarrow$ child interaction styles:

1. Optimum interaction style.

2. Interaction style - mother is silent, child speaks.

3. Interaction style - both are silent.

4. Interaction style - aggressive mother.

The characteristic features of adult-child interaction styles are analyzed in Table 1.

Table 1. Characteristic features of mother $\leftrightarrow$ childinter action styles (Иванова, 2004)

\begin{tabular}{|c|l|c|}
\hline Styles & \multicolumn{1}{|c|}{ Characterization of interaction styles } & $\begin{array}{c}\text { Occurrence } \\
\%\end{array}$ \\
\hline 1. & $\begin{array}{l}\text { Optimum. Mother and child have positive interaction: the child is } \\
\text { listened to; mother } \leftrightarrow \text { child actively engage in the conversation; child } \\
\text { looks mother in the eye, perceive her verbal responses, nonverbal } \\
\text { reactions. Child readily communicates with other adults. }\end{array}$ & 47,7 \\
\hline 2. & $\begin{array}{l}\text { Mother is silent, child speaks.Mother does not like child's } \\
\text { enthusiastic, emotional talking. The child is listened to in silence or } \\
\text { by instructing: "Calm down!", "Be silent!" or "Tell me later!". Child } \\
\text { tries to draw mother's attention by talking louder, more facial } \\
\text { expressions and gestures. That in turn fortifies the negative reaction } \\
\text { of mother - dislike of the child. }\end{array}$ & 29,7 \\
\hline 3. & $\begin{array}{l}\text { Both are silent.Child accustomed to not talking and does not try to } \\
\text { commence verbal communication with mother. When walking hand- } \\
\text { in-hand, mother } \leftrightarrow \text { child looks different directions, they don't talk; } \\
\text { both are characterized by emotionally blank facial expressions. }\end{array}$ & 14,1 \\
\hline 4. & $\begin{array}{l}\text { Aggressive mother.Between mother } \leftrightarrow \text { child there is aggressive } \\
\text { stance. Mother often yells, quarrels, shakes and sometimes even hits } \\
\text { the child. }\end{array}$ & 8,5 \\
\hline
\end{tabular}

Research shows that positive conditions for speech/ language development are created in $47,7 \%$ of children, in $52,3 \%$ of cases there is varied dissatisfaction of child interaction needs, that appears when the child is rejected from the necessary source of security (mother) thus creating unpredictable consequences in his development. 
Further in the research the author analyzes the link between child speech disorders and mother $\leftrightarrow$ child interaction styles (see Table 2).

It should be noted that the optimum interaction style influences child's speech/ language development in a relatively positive way. Every expression of negative attitude from the mother 1, 5 to 2 times reduces the number of children whose speech development corresponds to the accepted language norm at the specific age.

Table 2. Overview of child disorders in the context of different interaction styles (Иванова, 2004)

\begin{tabular}{|l|c|c|c|}
\hline \multirow{2}{*}{ Interaction style } & \multicolumn{3}{|c|}{ Child speech disorder \% } \\
\cline { 2 - 4 } & $\begin{array}{c}\text { No speech } \\
\text { disorder }\end{array}$ & $\begin{array}{c}\text { Light speech } \\
\text { disorder }\end{array}$ & $\begin{array}{c}\text { Severe speech } \\
\text { disorder }\end{array}$ \\
\hline 1. Optimum & 48 & 39 & 13 \\
\hline 2.Mother is silent, child speaks & 30 & 53 & 17 \\
\hline 3.Both are silent & 27 & 43 & 30 \\
\hline 4.Aggressive mother & 33 & 40 & 27 \\
\hline
\end{tabular}

If the mother is silent but the child speaks the number of children with light speech disorders increases 53\%). Child is interested in verbal communication, bet there is a lack of the repeated correct pronunciation by adult. Thus, the speech apparatus of the child is naturally exercised in articulation; however, there is no parallel correctively developing activity and the light speech disorders do not disappear but become stronger.

A more serious situation is seen in the case of the third interaction style both are silent, where the amount of severe speech disorders increases to $30 \%$. This case verifies the theory that child's speech activity is created only in the interaction between child and adult. If no one listens to the child talking then it becomes unnecessary. Child is silent, his speech skills do not form and consequently the speed of speech development is delayed.

Even in cases where the speech of children corresponds to the norms in a rather large amount (33\%), the attitude of an aggressive mother (fourth interaction style) greatly promotes not only severe speech disorders $(30 \%)$, but also intensified facial expressions, gestures, reactions, unnatural volume of the speech and inadequate (not fitting to the situation) behavior.

The mentioned research can be concluded with a very significant conclusion that in the ages of early childhood and preschool, when the biological and psychological connection of child with his mother is not yet severed, the child tries to express his thought verbally first and foremost to her, and the mother herself has the greatest possibilities to encourage, support and active the verbal communication. For this reason other adults (teacher, speech therapist) only partially can correct child's speech, only partially they can compensate the "moral absence" of the mother, as the main responsibility for a 
wholesome development of child's speech lies with the closest people - parents, mostly mother, who is irreplaceable.

Through analysis of the given situations we can conclude that the mutual mother $\leftrightarrow$ child relations do not promote development of child's personality and speech in $52,3 \%$ of cases which manifests in certain regularities:

- The tree main needs of a child - to belong and to be loved; need for self-esteem; need to acknowledge one - are not satisfied. It is known that parents love does not have to be deserved, it exists without any obligations. That means - to be with the child, help him be happy or sad, to work together (Kempbels, 1998);

- Child's attitude to himself, self-acceptance or non-acceptance, i.e., acknowledgment of self-esteem is created the evaluation of people around him. A child that receives few caresses feels the indifference or hostility of his parents, feels belittled. Self-esteem is taught and only a child with one can be brave independent, can realize himself in specific action, verbal communication included (Pučure, 2000);

- No emotions from mother during verbal communication that usually appear as glances, expressions, confirmation of child's thoughts. Child receives no answer when he asks questions and wants to satisfy his curiosity.

- There is a marked lack of active participation from mother's side in giving speech examples, no interest in interaction during child $\leftrightarrow$ adult.

The positive result of the research should be noted: in $47,7 \%$ of cases mothers are endowed with a unique and natural intuition - direct sensitive and intellectual apprehension of what the child needs, thus becoming positive companions in the process of speech/ language acquisition.

\section{The correlation of endogenous and exogenous factors in the speech/ language development}

Considering the influence of exogenous and endogenous factors on the development of a child, speech disorders can be relatively divided in three groups.

The first group is composed of children that require help of specialists due to various pathological conditions and illnesses. Thus, in case of decreasing hearing a consultation with audiologist; changes in the anatomical formation of the articulation apparatus will be eradicated by a surgeon; pathologies in the set of teeth will be corrected be an orthodontist; otolaryngologist will help eliminating the respiratory insufficiency, nasal speech, that is caused by tonsillitis, adenoids, polyps etc.

Therefore, in the given cases the specialists eradicate the causes that may induce deviation of speech development from the corresponding norm. 
However, in those cases when it is not possible to warn in time about the probability of a speech pathology, the effect of the harmful factor manifests itself already as a consequence to influence.

For instance, adenoidal formations complicate breathing through nose (child's mouth is always open), relax the tension of mouth muscles,tongue takes the wrong position (slides through teeth), creating sound pronunciation through teeth.Cooperation of at least two specialists is needed in this case otolaryngologist and a speech therapist - with an active participation of parents (Маталыгина, 2012).

The second group includes children with overall bodily movement immaturity, which appears in difficulties with large movements, articulation organs, performing small finger movements and differentiating.As the organism functions as a while, a physical inability directly affects psychical aspects perception, memory, attention, speech development (Miltina, 2005).

Speech problems are evident in sensory (phonematic hearing) errors inability to perceive and differentiate slight, different nuances in sounds; apperceptiveerrors -the unsteady attention of the child does not provide equal perception attitude towards separate parts of the heard material; movement errors - functioning of the articulation organs has not yet fully matured to pronounce the sound and its combinations precisely; reproduction errors child's memorization abilities do not correspond with the scope of perceptionthat determine the mistakes of words heard before (Тихеева, 1981).

For this reason these children require health strengthening activities, examples of correct pronunciation by adults, exercises of large (general) and small (hand) movements and the phonematic hearing. If a speech imperfection (sound is not pronounced, deformed or replaced) remains consistent and for a long period of time, it is viewed as a speech disorder and the child requires help of a specialist - teacher/ speech therapist. By not satisfying child's needs regarding speech development, the phonetically phonematic disorder of speech pronunciation as a consequence creates difficulties for child to perceive the spoken word; disorganizes the vocabulary; impedes the development of phonematic processes; complicates mastering reading and writing skills; negatively affects verbal communication with peers and adults, as well as child's self-assessment and self-esteem (Miltina, 2005).

The third group consists of children whose speech activity is reduced by the socially psychological factor (social environment) which determines the functional disorders of child's speech. The limited speech environment with insufficient imitation possibilities, as well as ignorance of pronunciation mistakes undoubtedly hinders speech development, creating and cementing lighter and more severe speech disorders. Already in the early childhood child himself expresses the initiative to communicate verbally and nonverbally with people around him - invites to play, tries to tell, ask things etc. The motivator of child's activity is needs, during interaction process these needs are conveyed in 
speech that develops through imitation of adults, thus the family becomes the first speech example. Child repeats the speech tempo, rhythm, andintonation of the caretakers he lives amongst.

Often there are the "silent parents" who hardly ever speak with the child, the also speak little among themselves. In such situation the child comes into a collision with himself: he cannot express himself, as no one answers his questions or careless words are uttered.

An important factor in the family creating speech disorders in majority of children is the speech errors made by care-takers themselves. The incorrect speech of the adult forms an inappropriate example for speech imitation that the child follows as there are no other examples.

Considering that children often imitate not only their own parents but also the speech of other adults, it is important to understand what values of other children of adults he is imitating, because not always the child comprehends what he says. Then explanations of word meanings are necessary, however, they often do not take place due to inattentiveness of adults (Смирнова, 2014).

Another factor influencing speech development is bilingualism - child's speech development is decelerated, in specific cases iterations appear "floundering" of non-spasmodic speech. When the family has a united approach towards language acquisition issues, the child can have a successive transition and consequently learn two or more language. The primary language the child acquires until the age of two is his mother's language, however, at the age of four the child starts to master the language of his father. Specific difficulties for a bilingual child can manifest in various manners: simultaneous use of words from both languages; due to mastering two languages formation of two different perception systems and generalization of each language takes place, which occurs in situations when both parents are equally involved in the learning process of both languages; difficulties arise with precise pronunciation of language sounds which in turn affects reading and writing skills; limitations of emotional vocabulary are observed, defined by the cultural and traditional features of the used language. It should be noted that speech errors (for instance, sound pronunciation disorders) that appear when learning the primary language, affect the clarity of sound pronunciation in the second language (Маталыгина, 2012, 8).

An example of speech disorder is the neurotic stammering (logoneurosis), which can appear in children with seemingly healthy central nervous system, that most often holds an enduring factor traumatizing the psyche (negative relationship between mother and father $\rightarrow$ divorce $\rightarrow$ "dividing" of the child in two families $\rightarrow$ rapid change of the style of upbringing etc.). Reactions to psycho-trauma appear as sudden fatigue of the child, sleep disorders, pronounced fear, stammering that develops gradually and occurs in waves. 
Arrangement and clarification of child's social environment will be the main factor that will stabilize his sense of security, facilitate the sense of familial belonging, strengthen his self-assurance, and promote his willingness to talk.

The speech activity is a socially defined process where a child uses names of objects, actions, characteristics in practical cooperation with an adult. Child receives the word from the outside, but it becomes his "property" through practical communication and speech utilization. Nowadays a child may have a minimal or maximal range of toys; however, there is often the lack of an adult as a mediator between the child and the new toy. Every new toy should be carefully looked at and its use accurately explained, that would facilitates child's orientation abilities in the world, accustoms the child to compare, contrast, and experiment, i.e., to think. Meeting everyinquiry need helps the child memorize the name of the object much faster than just by looking at the object.

Adult's speech during the cooperation process with child is important, it has commentary content. This speech possesses purposefulness, which is expressed in accompanying and promoting child's activities, evaluation of results, while the emotions of the adult attest the attitude towards child's achievements.

Feed-back (reflexive bond) has an essential significance in the child-adult relationship; positive bond affirms the child that his actions, statements, and questions are necessary, which in turn motivates the child for repeated activities and speech. Negative bond makes the child be aware of his inabilities, cease his activities, talking, and the adult, in child view, loses his status as adviser.

Therefore, everything stated before implies that in speech development and the eradication of speech disorders the parents - the adults closest to the child have the most important role. By teaching the child to pronounce correctly, remember words, use various situations, a communicative approach is used, i.e., in the process of speech perfection adults use linguistic and interaction approach in its entirety. Thus, the child gains greatly if the adults have time, knowledge, and willingness to help the child develop his communication competency, namely, implement wholesome speech activity in different communication forms (Трошин, Жулина, 2005; Смирнова, 2014, Dzintere, Stangaine, Augstkalne, 2014).

\section{Conclusions}

Taking into account the stated ideas about the influence of endogenous and exogenous factors on the emergence of speech disorders, we can see the following regularities:

- appearance of disorders is determined by various internal and external causes;

- family is the main facilitator or obstructer of child's speech development, as it is the speech environment where the child learns 
the appropriate verbal (language) and nonverbal (facial expressions, gestures, movements etc.) communication norms;

- $\quad$ the mother $\leftrightarrow$ child interaction style greatly influences child's speech. If his social needs are not satisfied, no one listens to the child, there is no example of correct speech, and then the activity of speech becomes unnecessary. As a result the speed of speech development is delayed, speech disorders fortify themselves, and skills of correct speech are not created.

\section{Summary}

A child is born with a speech apparatus prepared for speaking, however, he learns to speak gradually. "Speaking can be compared to a performance on a very complicated musical instrument that a person learns in early childhood and plays for the rest of his life" (Klavinna, 1997). Speech development is influenced by heredity and prenatal conditions, as well as surrounding and social environments. Child's speech development will be problematic if there are hereditary anomalies and the social environment does not provide the necessary preconditions for speech activity, motivation and cooperation with an adult.

By ignoring the apparent imperfections in child's speech the adults promote the fortification of speech disorders, therefore it is necessary to:

- in a timely mannerlisten to the specific peculiarities in child's speech;

- in timely manner seek the help of specialists and a speech therapist;

- in timely manner begin prophylactic activities to prevent factors that advance the emergence of speech disorders;

- $\quad$ only by working in a team- specialists $\leftrightarrow$ a speech therapist $\leftrightarrow$ adults, it is possible to anticipate positive results in preventing child's speech disorders.

\section{References}

Boulbijs, Dž. (1998). Drošais pamats. Vecāku un bērnu savstarpējā piek̦eršanās - cilvēka veselīgas attīstības priekšnoteikums. Rīga: Rasa ABC.

Dzintere, D., Stangaine, I., Augstkalne, D. (2014). Bērna komunikatīvās kompetences attīstība. Rīga: RaKa.

Falka, A. (2012). Aktualitātes iekļaujošajā izglītībā. Pal̄̄dzības iespējas bērniem ar speciālām vajadzībām vispārizglītojošās skolās. (Version viewed: www.livao.lv/upload/ ogre_7.11.12.falka.ppt (23.09.2014.)

Geske, R. (2005). Bērna biologiskā attīstība. Rīga: RaKa.

Irbe, A., Lindenberga, S., Miķelsone, L. (2003). Par savlaicīgu logopēdiski pedagoǵisko korekciju bērniem līdz 2 gadiem. Jums, kolēgi, Nr.2, 25.- 27.

Kempbels, R. (1998). Kā patiesi mīlèt savu bèrnu. Rīga: Amnis.

Kḷaviņa, S. (1997). Valodas daba. Ievads vispārīgajā valodniecībā. Lielvārde: Lielvārds.

Lūse, J., Miltiņa, I., Tūbele, S. (2012). Logopēdijas terminu skaidrojošā vārdnīca. Rīga: RaKa.

Miltiņa, I. (2013). Bērna runas un roku sīkās muskulatūras darbības mijsakarību aspekti. Valodu mācības pirmsskolā un sākumskolā. Rīga: LVA, 122. - 136.

Miltiņa, I. (2005). Skaņu izrunas traucējumi. Rīga: RaKa.

Pučure, I. (2000). Rotaļa - pirmsskolas vecuma bērnu pašapziņas sekmētāja. Bērns kā vērtība gimenè un pirmsskolā. Rīga: Izglītības soḷi, 37. - 45.

Puškarevs, I. (2001). Attīstības psihologija. Rīga: RaKa. 


\section{SOCIETY. INTEGRATION. EDUCATION. Volume III}

Skrule, J., Štāle, M., Upmale, S. (2009). Mātes un bērna veselība perinatālajā periodā. Publicēts valsts aǵentūra „Sabiedrības veselības aǵentūra”. (Versionviewed: http://sabves.spkc.gov.lv/ZinojumuDokumenti/Z_122/Zinojums_perinatala_aprupe.pdf (12.12.2014.)

Svešvārdu vārdnīca (1999). J.Baldunčikared. Rīga: Jumava.

Tomele, G.(2013). Rakstu valodas apguves un traucējumu korekcijas priekšnosacījumi Montesori pedagoǵijā. Sabiedrība, Integrācija, Izglìtība. Starptautiskās zinātniskās konferences materiāli. II daļa. Rēzekne: Rēzeknes augstskola, 222. - 233.

Баладина, Е.А. (2010). Факторы риска рождения детей расщелиной верхней губы и нёба в Пермском крае. Логопед. Научно-методический журнал, № 4, Москва: 6 - 12.

Волкова, Л.С. (2004). Логопедия. Москва: Владос.

Иванова, А.И. (2004). Влияние стиля общения с матерью на формирование речи ребенка. Логопед. Научно - методический журнал, Москва: № 4, 43 - 45.

Маталыгина, О.А. (2012). Развитие речи и профилактика её нарушений. Дошкольная педагогика, № 10, Санкт - Петербург: 4 -9.

Парамонова, Л.Т. (1997). Логопедия для всех. Санкт- Петербург: Дельта.

Смирнова, О.В (2014). Факторы предрасполагающие к возникновению речевых нарушений. Логопед. Научно - методический журнал, № 7, Москва:6 - 10.

Тихеева, Е.И. (1981). Развитие речи детей. Москва: Просвещение.

Трошин, О.В., Жулина, Е.В. (2005). Логопсихология. Москва: ТЦ „Сфера”. 